\title{
An Evaluation of Corporate Governance Characteristics and Corporate Performance between Government-Linked Companies (GLCs) in Malaysia and Singapore: A Panel Data Analysis
}

\author{
Ng Ching Yat David ${ }^{1, *}$, Lau Teck Chai ${ }^{2}$, Tee Peck Ling ${ }^{1}$, and Lai Siew Fong ${ }^{1}$ \\ ${ }^{1}$ Department of Accountancy, Faculty of Accountancy and Management, Universiti Tunku \\ AbdulRahman \\ ${ }^{2}$ Department of International Business, Faculty of Accountancy and Management, \\ Universiti TunkuAbdul Rahman
}

\begin{abstract}
This research seeks to investigate whether corporate governance contributes to the Government-link public listed companies' performance in Malaysia and Singapore. A sample consisting of 20 Malaysian Governmentlinked public listed companies and 20 Singaporean Government-linked public listed companies were selected. The research timeframe covers from 2012 to 2017. Findings revealed that except for board meetings and independent directors, 4 other independent variables were statistically significant in affecting the Malaysian and Singaporean government-link public listed companies' performance. Directors' ownership had a significant negative impact on ROA and ROE in Malaysia but had no impact in Singapore. Board meetings and independent directors had no impact towards firm performance in both countries. Board size had positive and significant impact on ROE in Singapore. Number of women directors was significantly negatively related to Tobin's Q, ROA and ROE. Leverage level was significantly negatively related to all firm performance's measures in Malaysia, while only significantly related to Tobin's Q in Singapore.
\end{abstract}

\section{Introduction}

The Malaysian Code on Corporate Governance (MCCG) was introduced in 2000. MCCG 2000 had defined clearly the best practices of CG that organization should clearly define ownership by both CEO and Chairman in order to prevent power dominance. It also mentioned that every organization need to take its board size into consideration in order to examine the impact of the board number on its effectiveness in monitoring and advising. The revised MCCG 2007 stressed on two major aspects which were board of directors and

\footnotetext{
*Corresponding author: ngcy@utar.edu.my
} 
audit committee. In another revision, MCCG 2012 provides 8 principles that achieved enhancement of board such as development of high sensitivity of responsible and effectiveness to increase composition, independence of directors, commitment, integrity in financial reporting, risk management, timely and high-quality disclosure and relationship between company and the interest of investors. The newly revised Code of MCCG 2017 detailed the importance of risk management. It stated that risk management should concentrate on internal control function which identified the threats and opportunities of the business. The Monetary Authority of Singapore (MAS) recommended changes and amendments to be made to the Companies Act, and that was when Singapore's firstCorporate Governance Code was established in year 2001. The Code was revised in 2005 and later in 2012. The Corporate Governance Council was introduced on 28 February 2017 to revise the Code, known as The Code 2018 with inserted Practice Guidance. The 2018 Code superseded and replaced the previous code that was issued in May 2012. The 2018 Code applied to Annual Reports effective from financial year commencing on 1 January 2019.

Although various studies were conducted investigating the performance of Malaysianand Singaporean Government-link public listed companies with corporate governance characteristics and their influence their performance, the revelation of a series of high-profile corporate governance scandals involving 1MDB, SRC International and FELDA by local and international media worldwide since year 2015 has stirred this area of research worth revisiting in order to narrow the knowledge gap. Additionally, there were few evidence on research conducted among government-link public listed companies.

\section{Literature Review and Hypothesis Development}

The ROA was ratio to determine the efficiency of the operating for the company based on the firm's gain profits from its total assets (Kabajeh et al., 2012). ROA also acted as an indicator to provide an overview how effective the firm utilize its total assets (Idawati \& Wahyudi, 2015). The ROE was a ratio used to provide an overview to describe how much profit each dollar of stock can be generated. ROE means the profit that shareholders can be generated from their investment. ROE acts as a short-cut method to judge whether their investment was making money or not. However, ROE does not provide a detailed view of the firm performance (Hagel, Brown, Samoylova, \& Lui, 2013). The Tobin's Q ratio equals to the total market value of a corporation divided by its total assets' replacement cost. Thus, equilibrium was market value equals replacement cost. The $\mathrm{Q}$ ratio was calculated as the market value of a company divided by the replacement value of the firm's assets. Tobin's $Q$ has been extensively used in the empirical literature as a proxy for firm performance (Hennessy, 2004).

\subsection{Relationship between Director Ownership (DO) and Firm performance}

Directors' ownership was one of the important factors that can significantly affect the corporate performance. When board directors own a portion of the organization's share, board directors' interests associate with the interests of other shareholders. This presents that directors' ownership had positive association with firm performance and it had negative association with agency conflict (Nazar, 2012). Organization will face two typesof agency problem which were the conflict between principal and principal and the conflict between agent and principal. Principal-principal conflict focused on whether the controlling shareholders can fully utilize the resources acquired from the other shareholders for their own interest. This support that the occurrence of principal-principal conflict that brought negative impact to the relationship between independent directors and firm performance (Nguyen, Evans, \& Lu, 2017). According to the research of Mat Nor, Shariff, and Ibrahim (2010), their 
research supported that directors' ownership was negatively and significantly related to the corporate performance. This means higher board director ownership enabled them to entrench themselves and invest on the project that served their interest. Htay et al. (2011) supported that the concentration of ownership was negatively and insignificantly related to the corporate performance especially if it was held by the insiders. According to Elvin \& Hamid (2016), their findings supported that directors' ownership was positively and significantly influenced the corporate performance. Based on research of Ghazali(2010), the findings supported that government as a substantial shareholder and foreign ownership were significantly influenced the firm performance which measured by Tobin's Q.

$\mathrm{H} 1_{1 \mathrm{~A}}$ : Director ownership is positively and significantly related with Tobin's Q.H1 $1_{1 \mathrm{~B}}$ : Director ownership is positively and significantly related with ROA. H1 $1_{1 \mathrm{C}}$ : Director ownership is positively and significantly related with ROE.

\subsection{Relationship between Average Number of Board Meetings (BM) per Year andFirm Performance}

Board meetings was a critical factor that could improve the firm performance. The frequency of board meetings to discuss different issue that raised against the organization which significantly affected the effectiveness of the board (Amer et al., 2014). Board meetings was all the directors spend limited time together was not useful for them to exchange meaningful ideas among them. Furthermore, based on Harvey et al. (2015), the purpose of their study was to investigate the relationship between CG mechanisms and performance of firms in South Africa. They found that board meetings negatively and significantly related to firm performance. According to Liang, Xu and Jiraporn (2013), theirresearch findings supported that board meeting was positively and significantly related to firm performance. In addition, the study of Sahu and Manna (2013) also provided a same result with Liang, Xu and Jiraporn (2013). Research of Al-matari, Al-Swidi, and Btfadzil (2014), thy found that board meetings had positive insignificant relationship with firm performance. Their study used 81 listed companies on the Muscat Security Market (MSM) in Oman covering two years period 2011 and 2012. Thus, the hypothesis was formed in order to define the relationship between the BM and firm performance (ROA, ROE and Tobin's Q) in Malaysian and Singapore Government-link public listed companies.

$\mathrm{H}_{2 \mathrm{~A}}$ : Average number of board meetings per year is positively and significantly related with Tobin's Q.

$\mathrm{H}_{2 \mathrm{~B}}$ : Average number of board meetings per year is positively and significantly related with ROA.

$\mathrm{H}_{2 \mathrm{C}}$ : Average number of board meetings per year is positively and significantly related with ROE.

\subsection{Relationship between Board Size (BS) and Firm Performance}

Based on the past study, some of the paper argued that larger BS will lead to better firm performance (Dalton, D. R., \& Daily, 2000). However, there were also some past studies preferred smaller BS (Lipton, 1992; Fama \& Jensen, 1983). The increased of the BS, the coordination become more obviously and decreased of the effectiveness of interpersonal communication among the board directors (Anis et al., 2017). Agency costs appeal which leads to smaller BS provide greater CEO domination of board, however larger BS provide advantage to the firms through offer effective oversight of management and this enable the firm to choose the obtainable necessary resources and providing representation of various 
stakeholders within the firm (Amer et al., 2014). The Company Articles of Associations Malaysia provided that a company must had not less than 2 directors and not more than 12 directors. According to the study developed by Amer et al. (2014), their study supported that BS was positively and significantly related to the firm performance. Furthermore, study developed by Johl et al. (2015), their study conducted the sample of Malaysia public listed companies on the Bursa Malaysia based on market capitalization as of 31 December 2009. The findings of this study showed BS was positively related to the firm performance. According to Kalsie and Shrivastav (2016), their research showed that BS had a positive and significant relationship with firm performance. Resource dependency theory argued that larger BS increase the connection with external parties in order to bring variety of skillsand knowledge in various field to improve the function of the organizations.

$\mathrm{H1}_{3 \mathrm{~A}}$ : Board size is positively and significantly related with Tobin's Q.H1 $1_{3 \mathrm{~B}}$ : Board size is positively and significantly related with $\mathrm{ROA}$. $\mathrm{H}_{3 \mathrm{C}}$ : Board size is positively and significantly related with ROE.

\subsection{Relationship between Independent Directors (ID) and Firm Performance}

The concept of ID is simple. Directors were expected to be independent from the management and gain full trust and act in best interest of shareholders. ID were obligated to evaluate the performance and wellbeing of a company without having any conflict of interest or undue influence. According to MCCG 2017, it was recommended that for a largecompany, they were required to have consist at least 1/3 of ID in their board. This is to ensure good decision making were done for the firm with no undue influence or conflict of interest. One of the studies on firm performance or firm financial performance and board sizeand board composition for companies quoted on Bucharest Stock Exchange indicated that the number of ID and firm performance had a negative relationship (Moscu, 2013). This explains that when the number of non-executive directors' increase, the firm performance decreased. In contradict, most of the studies showed positive indication of independent directors towards firm performance. According to Rahman, Ibrahim, \& Ahmad (2015), their research study resulted in independence of the board will improve firm performance and shareholders' confidence, which indicates that ID were significantly affected firm's performance positively. From a study measured by Tobin's Q on firm's performance, it wasshown that the proportion of non-executive directors (NEDs) on the board was both positive and significant, and the study also suggested that companies with higher proportions of NEDs seem to perform better than those with lower proportions of NEDs (Abidin, Kamal, \& Jusoff, 2009). There was no significant difference in performance between firms with independent boards and firm with non-independent boards (Mohd Nor, Shafee, \& Samsuddin, 2014).

$\mathrm{H} 1_{4 \mathrm{~A}}$ : Independent directors is positively and significantly related to Tobin's Q.H1 ${ }_{4 \mathrm{~B}}$ Independent directors is positively and significantly related to ROA. H14C: Independent directors is positively and significantly related to ROE. 


\subsection{Relationship between Number of Women Directors (NWD) and Firm Performance}

MCCG 2017 stated in Practice 4.5 that the board must disclose in its annual report the company's policies on gender diversity. For large corporation, women directors on board must have at least $30 \%$. Past research had shown mixed results of the impact of women directors towards firm performance. According to a past research, the results shown insignificant indication of women gender board diversity towards firm's performance (Yasser, 2012). Also, an empirical study on Italy deduced a result which stated that there was no significant impact of women directors towards firm's performance (Shabbir, 2018). According to Triana \& Marwan Asri (2017), the empirical result showed that a female director had a positive significant effect on firm performance. Julizaerma \& Sori (2012) study showed a positive significant association happened between gender board diversity and firm performance. Besides, based on a study of Puthenpurackal \& Upadhyay (2010), it was mentioned that women directors with more experience were associated with higherfirm performance. In the context of large European firm, the study resulted in positive relationship of female board representation on firm's performance (Green \& Homroy, 2018). According to Triana \& Marwan Asri (2017), evidence from Vietnam indicated negative effect of the ratio of independent female directors on firm performance.

$\mathrm{H} 1_{5 \mathrm{~A}}$ : Number of women directors is positively and significantly related to Tobin's Q.H1 $1_{5 \mathrm{~B}}$ : Number of women directors is positively and significantly related to ROA. H1 $1_{5 \mathrm{C}}$ : Number of women directors is positively and significantly related to ROE.

\subsection{Relationship between Leverage Level (LL) and Firm Performance}

An abundance of research in the literature had been performed on how LL brought impact towards firm performance. A result based in Pakistan defined that financial leverage was negatively associated with ROA and ROE, which showed that firms borrow less, while market-to-book ratio showed positive profitable association with firms (Hussain Javed et al., 2015). Based on the study conducted by Raza (2013) showed negative relation between firm's performance and LL. Besides, according to a sample from Amman Stock Exchange, the study results in financial leverage having a negative relationship with firm performance (Abu-Abbas, n.d.). A study in Kenya also supported that LL was negatively significantly related to firm's performance (Mwangi, Makau, Kosimbei, \& Pouraghajan, 2012). From an evidence from Cement Sector of Pakistan, there was significant negative relationship between working capital management and firm performance (Iqbal, Raza, Farrukh, \& Mubeen, 2016).

$\mathrm{H}_{6 \mathrm{~A}}$ : Leverage Level is negatively and significantly related to Tobin's Q.H1 ${ }_{6 \mathrm{~B}}$ : Leverage Level is negatively and significantly related to ROA. $\mathrm{H}_{6 \mathrm{C}}$ : Leverage Level is negatively and significantly related to ROE.

\section{Methodology}

The study seeks to determine the impact between Corporate Governance characteristics and firm performance (Tobin's Q, ROA and ROE) of Malaysian and Singaporean Governmentlink public listed companies covering a period of 6 years: 2012 to 2017. This research focuses on quantitative data - cross-sectional and longitudinal analysis. Data was acquired from Bursa Malaysia and Singapore Exchange Limited from 2012 to 2017. Two alternative panel data regression models were adopted in the EViews statistical software, which were the Fixed Effect model and the Random Effect model, to test the dataset collected. 


\section{Research Results}

Refer to Table 4 and 5 on the discussion on the panel data analysis for both Malaysia and Singapore.

Table 1: Governance Characteristics and Firm Performance

\begin{tabular}{|c|c|c|c|c|c|c|}
\hline & \multicolumn{2}{|l|}{ Tobin's Q } & \multicolumn{2}{|l|}{ ROA } & \multicolumn{2}{|l|}{ ROE } \\
\hline & Malaysia & Singapore & Malaysia & Singapore & Malaysia & Singapore \\
\hline DO & 0.461 & 0.965 & $-0.006 *$ & 0.416 & $-0.033 *$ & 0.940 \\
\hline $\mathrm{BM}$ & 0.459 & 0.177 & 0.816 & 0.455 & 0.837 & 0.909 \\
\hline $\mathrm{BS}$ & 0.555 & 0.489 & 0.198 & 0.154 & 0.380 & $+0.040 *$ \\
\hline ID & 0.331 & 0.990 & 0.796 & 0.929 & 0.965 & 0.228 \\
\hline NWD & $-0.009 *$ & $-0.005 *$ & $-0.000 *$ & $-0.000 *$ & $-0.000 *$ & $-0.000 *$ \\
\hline LL & $-0.000 *$ & $-0.000 *$ & $-0.000 *$ & 0.896 & $-0.000 *$ & 0.745 \\
\hline Constant & 0.000 & 0.000 & 0.000 & 0.519 & 0.000 & 0.064 \\
\hline
\end{tabular}

Table 2: Hausman Test

\begin{tabular}{|l|l|l|l|l|}
\hline $\begin{array}{l}\text { Dependent } \\
\text { variables }\end{array}$ & P-value & Remarks & \\
\hline & Malaysia & Singapore & Malaysia & Singapore \\
\hline Tobin's Q & 0.0126 & 0.0000 & Fixed Effect Model & Fixed Effect Model \\
\hline ROA & 0.0053 & 0.0026 & Fixed Effect Model & Fixed Effect Model \\
\hline ROE & 0.0015 & 0.0741 & Fixed Effect Model & Random Effect \\
& & & & Model \\
\hline
\end{tabular}

Tobin's $Q=2.53+0.0025 D O-0.0097 B M+0.013 B S+0.022 I D-0.067 N W D-2.40 L L$ $+0.32 \varepsilon$

DO and BS and ID were positively affected Tobin's Q. The others 3 variables were negatively related to Tobin's Q. Fixed effect analysis for Tobin's Q for 6 years research was investigating based on 6 years basis, the data presented there were 2 independent variables was significant impact Tobin's Q which were NWD and LL which probability value was 0.0093 and 0.0 respectively which were less than alpha 0.05 . Therefore, there was insufficient evidence to reject $\mathrm{H}_{5 \mathrm{~A}}$ while there was sufficient evidence to reject $\mathrm{H}_{6 \mathrm{~A}}$. The Hausman test statistic presented that the probability value was 0.0126 which less than alpha 0.05 , thus the most appropriate regression was fixed effect model to explain Tobin's Q.

\section{Tobin's Q- Singapore}

Tobin's $Q=1.60-0.00038 D O-0.024 B M+0.019 B S-0.00038 I D-0.098$ NWD - 0.011 LL $+0.42 \varepsilon$

BS was the only variable that positively affected Tobin's Q. The other 5 variables were negatively related to Tobin's Q. Fixed effect analysis for Tobin's Q for 6 years research was investigating based on 6 years basis, the data presented there are 2 independent variables were significant impact on Tobin's Q which were NWD and LL which probabilityvalue was 0.0050 and 0.00001 respectively which were less than alpha 0.05 . Therefore, there was insufficient evidence to reject $\mathrm{H}_{5 \mathrm{~A}}$ while there was sufficient evidence to reject $\mathrm{H}_{6}$. The Hausman test statistic presents that the probability value is 0.0000 which is less than alpha 0.05 , thus the most appropriate regression is fixed effect model to explain Tobin's Q. 


\section{ROA- Malaysia}

$\boldsymbol{R O A}=25.19-0.10 \mathrm{DO}-0.032 B M-0.30 B S+0.062 I D-1.14 \mathrm{NWD}-23.07 L L+3.30 \varepsilon$

ID was positively related to ROA while others 5 variables such as DO, BM, BS, NWD and LL were negatively related to ROA. Fixed effect analysis for ROA for 6 years research was investigating based on 6 years basis, the data presented there were 3 independent variables were significant affected ROA which were DO, NWD and LL which probability value is $0.0064,0.00$ and 0.00 respectively which were less than alpha 0.05 . There was insufficient evidence to reject $\mathrm{H}_{1 \mathrm{~B}}$ and $\mathrm{H} 0_{5 \mathrm{~B}}$. However, there were sufficient evidence to reject $\mathrm{H}_{6} \mathrm{~B}$. The Hausman test statistic presents that the probability value was 0.0053 which less than alpha 0.05 therefore the most appropriate model was fixed effect model to explain ROA.

\section{ROA- Singapore}

$\boldsymbol{R O A}=2.87+0.075 \mathrm{DO}-0.14 B M+0.41 B S-0.030 I D-1.8 \mathrm{NWD}+0.0038 L L+4.43 \varepsilon$

DO, BS, and LL were positively related to ROA while the other 3 variables BM, ID, and NWD were negatively related to ROA. Fixed effect analysis for ROA for 6 years research was investigating based on 6 years basis, NWD was significant affect ROA which probability value was 0.00 which are less than alpha 0.05 . Therefore, there were insufficientevidence to reject $\mathrm{H}_{5 \mathrm{~B}}$. The Hausman test statistic presented that the probability value was 0.0026 which was less than alpha 0.05 , therefore the most appropriate model was fixed effect model to explain ROA.

\section{ROE- Malaysia}

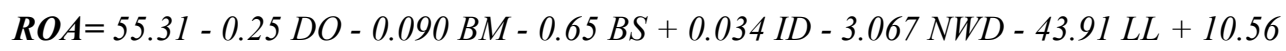

ID was positively related to ROA while others 5 variables such as DO, BM, BS, NWD and LL were negatively related to ROA. Fixed effect analysis for ROE for 6 years research was investigating based on 6 years basis, the data presents there were 3 independent variables was significant affected ROE which were DO, NWD and LL which probability value was 0.0333 , 0.0005 and 0.0009 respectively which were less than alpha 0.05 . There was insufficient evidence to reject $\mathrm{H}_{1 \mathrm{C}}$ and $\mathrm{H}_{5} \mathrm{C}$. However, there were sufficient evidence to reject $\mathrm{H}_{66}$. The Hausman test statistic presented that the value probability was 0.0015 which less than alpha 0.05 therefore the most appropriate model was fixed effect model to explain ROE

\section{ROE- Singapore}

$$
\boldsymbol{R O E}=11.58-0.0054 \mathrm{DO}-0.058 \mathrm{BM}+1.31 \mathrm{BS}-0.86 \mathrm{ID}-4.01 \mathrm{NWD}-0.026 L L+6.21 \varepsilon
$$

BS was positively related to ROE while the other 5 variables such as directors ownership, number of board meetings, number of independent directors, number of women directors and leverage level were negatively related to ROE. Random effect analysis for ROE for 6 years research was investigating based on 6 years basis, the data presents there were 2 independent variables that significant affected ROE which are BS and NWD which the probability value was 0.0409 and 0.0000 respectively which were less that board size alpha 
0.05. Thus, there were sufficient evidence to reject $\mathrm{H}_{3} \mathrm{C}$ while there was insufficient evidence to reject $\mathrm{H}_{5 \mathrm{C}}$. The Hausman test statistic presented that the value probability was 0.0741 which was more than alpha 0.05 therefore the most appropriate model was random effect model to explain ROE.

\section{Conclusion}

This study was conducted to understand and determine if CG characteristics impacted corporate performance on government-link public listed companies in Malaysia and Singapore. Findings determined that CG characteristics were not statistically significant in affecting Malaysia and Singapore government-link public listed companies' performance. Although Malaysia and Singapore government-link public listed companies had taken initiatives to improve their management and overall performances by implementing CG practices, company performance may have been affected by various external and internal factors in a volatile business environment. The panel data analysis in this research revealed that directors' ownership was negatively and significantly affect ROA this indicated that greater directors' ownership will bring poorer ROA and directors' ownership was negatively and significantly influenced ROE this showed that decreased directors' ownership would bring greater ROE in Malaysia, however, directors' ownership had no impact in Singapore. Furthermore, the number of board meetings has no impact for both Malaysia and Singapore. As for board size, findings showed that there was positively and significantly related with ROE in Singapore, this indicated that greater board size will lead better ROE. However, board size had no impact towards firm performance in Malaysia and Tobin's Q and ROA in Singapore. In addition, the number of independent directors had no impact for both firm performance in Malaysia and Singapore. From the findings, it presented that number of women directors was negatively and significantly affected firm performance in Malaysia and Singapore. This indicated that lower proportion of female directors will led better firm performance for both countries. Furthermore, leverage level was negatively and significantly affected firm performance in Malaysia (Tobin's Q, ROA and ROE) and Singapore (Tobin's Q).

\section{REFERENCES}

Abidin, Z. Z., Kamal, N. M., \& Jusoff, K. (2009). Board structure and corporate performance in Malaysia. International Journal of Economics and Finance, 1(1), 150-164. https://doi.org/10.5539/ijef.v1n1p150

Abu-Abbas, B. (n.d.). Financial leverage and firm performance: evidence from Amman Stock Exchange.

Al-matari, E. M., Al-Swidi, K. A., \& Btfadzil, H. F. (2014). The effect on the relationship between board of directors characteristics on firm performance in Oman. Middle East Journal

$$
\text { of Scientific Research, 21(3), }
$$

556-574.https://doi.org/10.5829/idosi.mejsr.2014.21.03.21410

Amer, M., Ragab, A. A., \& Ragheb, M. A. (2014). Board characteristics and firm performance: evidence from New Zealand. Auckland University of Technology, 8(5), 1132. https://doi.org/10.5901/ajis.2015.v4n1p283

Anis, M., Chizema, A., Lui, X., \& Fakhreldin, H. (2017). The Impact of board characteristics on firms financial performance - Evidence from the Egyptian listed companies. Global Journal of Human-Social Science: H Interdisciplinary, 17(5), 1-103.

Badu, L. A., \& Appiah, K. O. (2017). The Impact of corporate board size on firm performance: Evidence from Ghana and Nigeria. Research in Business and Management, 4(2), 1. https://doi.org/10.5296/rbm.v4i2.11721 
Dalton, D. R., \& Daily, C. M. (2000). Board and financial Performance, the bigger is better. Journal of Management, 1157-1177.

Elvin, P., \& Hamid, N. I. N. A. (2016). Ownership structure, corporate governance and firm performance. International Journal of Economics and Financial Issues, 6(S3), 99-108. https://doi.org/10.1108/10867371211266937

Fama, E. F., \& Jensen, M. C. (1983). Separation of ownership and control. The Journal of Law and Economics, 26(2), 301-325. https://doi.org/10.1086/467037

Ghazali, N. A. M. (2010). Ownership structure, corporate governance and corporate performance in Malaysia. International Journal of Commerce and Management, 20(2), 109119. https://doi.org/10.1108/10569211011057245

Green, C. P., \& Homroy, S. (2018). Female directors, board committees and firm performance.

$$
\begin{aligned}
& \text { European Economic Review, 102(1), } \\
& \text { 19-38.https://doi.org/10.1016/j.euroecorev.2017.12.003 }
\end{aligned}
$$

Hagel, J., Brown, J. S., Samoylova, T., \& Lui, M. (2013). Success or struggle : ROA as a true measure of business performance. Deloitte University Press, 4-18.

Harvey, P. ., Chamisa, E., Abdulla, C., \& Smith, C. (2015). An analysis of corporate governance and company performance: A South Africa perspective. South African. Journal of Accounting Research, 29(2), 115-131.

Hennessy, C. A. (2004). Tobin's Q, debt overhang, and investment. Journal of Finance. https://doi.org/10.1111/j.1540-6261.2004.00677.x

Htay, S. N., Rashid, H. M. A., Adnan, M. A., \& Meera, A. K. M. (2011). Corporate governance and risk management information disclosure in Malaysian Listed Banks : Panel data analysis. International Review of Business Research Papers, 7(4), 159-176.

Hussain Javed, Z., Rao, H., Akram, B., Fayyaz Nazir M., Zakeriya University, B., \& Cand, Mp. (2015). Effect of financial leverage on performance of the firms: Empirical evidence from Pakistan. Journal of Economics and Business, 65(1), 87-95. https://doi.org/10.1002/jez.b.00036

Idawati, W., \& Wahyudi, A. (2015). Effect of earning per share (EPS) and return on assets (ROA) against share price on coal mining company listed in Indonesia stocks exchange. Journal of Resource Development and Management, 7(June 2016), 79-92.

Iqbal, A., Raza, H., Farrukh, M., \& Mubeen, M. (2016). Impact of leverages on share price: Evidence from cement sector of Pakistan. Industrial Engineering Letters, 6(6), 44-48.

Johl, S. K., Kaur, S., \& Cooper, B. J. (2015). Board characteristics and firm performance: Evidence from Malaysian public listed firms. Journal of Economics, Business and Management, 3(2), 239-243. https://doi.org/10.7763/JOEBM.2015.V3.187

Julizaerma, M. K., \& Sori, Z. M. (2012). Gender diversity in the boardroom and firm performance of Malaysian public listed companies. Procedia - Social and Behavioral Sciences, 65(ICIBSoS), 1077-1085. https://doi.org/10.1016/j.sbspro.2012.11.374

Kabajeh, M. A., AL Nu'aimat, S. M., \& Dahmash, F. N. (2012). The relationship between the ROA, ROE and ROI ratios with Jordanian insurance public companies market share prices, International Journal of Humanities and Social Science, 2(11), 115-120.

Kalsie, A., \& Shrivastav, S. M. (2016). Analysis of board size and firm performance: Evidence from NSE companies using panel data approach. Indian Journal of Corporate Governance, 9(2), 148-172. https://doi.org/10.1177/0974686216666456 
Liang, Q., Xu, P., \& Jiraporn, P. (2013). Board characteristics and Chinese bank performance. Journal of Banking \& Finance, 37(8), 1-46.

Lipton, M. (1992). A modest proposal for improved corporate governance. The Business Lawyer, 59-77.

Mat Nor, F., Shariff, F. M., \& Ibrahim, I. (2010). The effects of concentrated ownership on the performance of firms: Do external shareholdings and board structure matter'? Jurnal Pengurusan, 30, 93-102.

Mohd Nor, M., Shafee, N. B., \& Samsuddin, N. (2014). Board characteristics and Malaysian firm performance. Global Journal of Business Research in Accounting, Auditing and Business Ethics, (3), 139-147. https://doi.org/10.3145/epi.2017.jul.20

Moscu, R. (2013). The Relationship between firm performance and board characteristics in Romania. International Journal of Academic Research in Economics and Management Sciences, 2(1), 167-175.

Mwangi, L. W., Makau, S. M., Kosimbei, G., \& Pouraghajan, A. (2012). Relationship between capital structure and performance of non-financial companies listed in the Nairobi Securities Exchange, Kenya. Global Journal of Contemporary Research in Accounting, Auditing and Business Ethics (GJCRA), 1(9), 72-90.https://doi.org/10.11648/j.jfa.20130103.11

Nazar, M. C. A. (2012). The relationship between board characteristics and firm performance of Sri Lankan listed companies. Business and Management, 6(2), 343-350.

Nguyen, T. T. M., Evans, E., \& Lu, M. (2017). Independent directors, ownership concentration and firm performance in listed companies. Pacific Accounting Review, 29(2), 204-226. https://doi.org/10.1108/PAR-07-2016-0070

Puthenpurackal, J., \& Upadhyay, A. (2010). Board gender diversity and firm performance: The impact of information environment. Twenty Years after Cadbury, Ten Years after Sarbanes-Oxley: Challenges of Corporate Governance.

Rahman, H. U., Ibrahim, M. Y., \& Ahmad, A. C. (2015). Corporate governance, firm financial performance and shareholders' confidence: A proposed analysis of MCCG 2012. Global Business \& Management Research: An International Journal, 7(1), 139-147.

Raza, M. W. (2013). The effect of financial leverage on firm performance: Empirical evidence from Karachi Stock Exchange. Canadian Journal of Regional Science, 50383(September 2013), 1-20. https://doi.org/10.1227/01.NEU.0000349921.14519.2A

Sahu, T. ., \& Manna, A. (2013). Impact of board composition and board meeting on firms' performance: A study of selected Indian companies. Vilakshan. XIMB Journal, 10(2), 99112.

Shabbir, M. (2018). Women on corporate boards and firm performance, preliminary results from Italian listed companies after the introduction of gender quota law 120/2011. Journal of Business and Financial Affairs, 7(1), 1-6. https://doi.org/10.4172/2167-0234.1000316 Triana, \& Marwan Asri. (2017). The impact of female directors on firm performance: Evidence from Indonesia. Journal of Indonesian Economy and Business, volume 31(1), 19 32. https://doi.org/10.22146/jieb.21994

Yasser, Q. R. (2012). The effects of female directors on firms' performance in Pakistan. Modern Economy, 03(07), 817-825. https://doi.org/10.4236/me.2012.37104 